Check for updates

Cite this: Chem. Commun., 2020,

56,11787

Received 11th July 2020,

Accepted 24th August 2020

DOI: $10.1039 / \mathrm{d} 0 \mathrm{cc} 04789 a$

rsc.li/chemcomm

\section{A NiRhS fuel cell catalyst - lessons from hydrogenase $\dagger$}

\author{
Seiji Ogo, (D) *ab Tatsuya Ando, ${ }^{\text {ab }}$ Le Tu Thi Minh, ${ }^{a}$ Yuki Mori, ${ }^{a}$ \\ Takahiro Matsumoto, ${ }^{a b}$ Takeshi Yatabe, ${ }^{a b}$ Ki-Seok Yoon, ${ }^{a b}$ Yukio Sato, ${ }^{c}$ \\ Takashi Hibino iD bd and Kenji Kaneko (iD bc
}

We present a novel fuel cell heterogeneous catalyst based on rhodium, nickel and sulfur with power densities $5-28 \%$ that of platinum. The NiRhS heterogeneous catalyst was developed via a homogeneous model complex of the [NiFe]hydrogenases $\left(\mathrm{H}_{2}\right.$ ases) and can act as both the cathode and anode of a fuel cell.

We have previously reported a NiRu model complex, $\left[\mathrm{Ni}^{\mathrm{II}}(\mathrm{X})\right.$ $\left.\left(\mathrm{H}_{2} \mathrm{O}\right)(\mu-\mathrm{H}) \mathrm{Ru}^{\mathrm{II}}\left(\eta^{6}-\mathrm{C}_{6} \mathrm{Me}_{6}\right)\right]\left(\mathrm{NO}_{3}\right)\left\{[3]\left(\mathrm{NO}_{3}\right), \mathrm{X}=N, N^{\prime}\right.$-dimethyl3,7-diazanonane-1,9-dithiolato\}, which can mimic the chemical functions of $\mathrm{O}_{2}$-tolerant $[\mathrm{NiFe}] \mathrm{H}_{2}$ ases. ${ }^{1-3}$ This complex is based on a central NiRu bimetallic core with flexible $\mu$-S bridges, which allow the close approach of the two metal centres. This complex can perform both $\mathrm{H}_{2}$-oxidation and $\mathrm{O}_{2}$-reduction, in a similar manner to $\mathrm{O}_{2}$-tolerant $[\mathrm{NiFe}] \mathrm{H}_{2}$ ases, ${ }^{1,3,4}$ and thus acts as both an anode and a cathode catalyst for $\mathrm{H}_{2}-\mathrm{O}_{2}$ fuel cells. ${ }^{5}$ However, the successful functioning of the compound did not extend as far as producing an efficient fuel cell. ${ }^{5}$ Since organometallic catalysts are not as robust as their solid-state, heterogeneous counterparts, we investigated the possibility of using dry distillation (pyrolysis) to remove the volatile elements and leave behind the active $\mu$-S bimetallic core. We investigated three bimetallic complexes, where nickel was partnered with ruthenium, rhodium and iridium and the NiRh complex gave the best results.

Herein, we describe the synthesis, characteristics and catalytic properties of the NiRh organometallic complex before detailing its conversion into NiRhS dry-distilled catalysts (DDCs). We then

\footnotetext{
${ }^{a}$ Department of Chemistry and Biochemistry, Graduate School of Engineering, Kyushu University, International Institute for Carbon-Neutral Energy Research (WPI-I2CNER), Kyushu University, 744 Moto-oka, Nishi-ku, Fukuoka 819-0395, Japan.E-mail: ogo.seiji.872@m.kyushu-u.ac.jp

${ }^{b}$ Center for Small Molecule Energy, Kyushu University, 744 Moto-oka, Nishi-ku, Fukuoka 819-0395, Japan

${ }^{c}$ Department of Materials Science and Engineering, Faculty of Engineering, Kyushu University, 744 Moto-oka, Nishi-ku, Fukuoka 819-0395, Japan

${ }^{d}$ Graduate School of Environmental Studies, Nagoya University, Furo-cho, Chikusa-ku, Nagoya 464-8601, Japan

$\dagger$ Electronic supplementary information (ESI) available: Experimental details, Tables S1-S9 and Fig. S1-S22. CCDC 1996959 and 1996960. For ESI and crystallographic data in CIF or other electronic format see DOI: 10.1039/d0cc04789a
}

demonstrate the catalytic properties of these dry-distilled compounds and their application as the first DDCs containing two different metals and sulfur that function as both the anode and cathode of functioning fuel cells (Fig. S1 and Table S1, ESI $\dagger$ ). ${ }^{6}$

$\mathrm{A} \mathrm{Ni}^{\mathrm{II}} \mathrm{Rh}^{\mathrm{III}}$ dichloride complex [ $\left.\mathrm{Ni}^{\mathrm{II}} \mathrm{Cl}(\mathrm{X}) \mathrm{Rh}^{\mathrm{III}} \mathrm{Cl}\left(\eta^{5}-\mathrm{C}_{5} \mathrm{Me}_{5}\right)\right]$ (1) was prepared from the reaction of $\left[\mathrm{Ni}^{\mathrm{II}}(\mathrm{X})\right]$ with $\left[\mathrm{Rh}^{\mathrm{III}}\left(\eta^{5}-\mathrm{C}_{5} \mathrm{Me}_{5}\right) \mathrm{Cl}_{2}\right]_{2}$. This water-soluble complex was then characterized by X-ray analysis (Fig. S2 and Table S2, ESI $\dagger$ ), electrospray ionization-mass spectrometry (ESI-MS, Fig. S3, ESI $\dagger$ ) and ${ }^{1} \mathrm{H}$ NMR (Fig. S4, ESI $\dagger$ ) and IR spectroscopies (Fig. S5, ESI $\dagger$ ). Its structure is based around a $\mathrm{Ni}(\mu-\mathrm{S})_{2} \mathrm{Rh}$ butterfly core, which is similar to our previouslyreported $[\mathrm{NiFe}] \mathrm{H}_{2}$ ase mimics. ${ }^{1,7}$

Having synthesized 1, we proceeded to investigate its catalytic properties. Complex 1 activated $\mathrm{H}_{2}(0.1 \mathrm{MPa})$ heterolytically in water to afford a $\mathrm{Ni}^{\mathrm{II}} \mathrm{Rh}^{\mathrm{III}}$ hydride complex $\left[\mathrm{Ni}^{\mathrm{II}} \mathrm{Cl}(\mathrm{X})(\mu-\mathrm{H}) \mathrm{Rh}^{\mathrm{III}}-\right.$ $\left.\left(\eta^{5}-\mathrm{C}_{5} \mathrm{Me}_{5}\right)\right](2)$ in a similar manner to $\mathrm{H}_{2}$ ases (Fig. 1 and 2a). ${ }^{1,3,7,8}$ The structure was determined by X-ray analysis (Fig. 1), UV-vis spectroscopy (Fig. S6 and Tables S2 and S3, ESI $\dagger$ ), ESI-MS (Fig. S7, ESI $\dagger$ ) and IR spectroscopy (Fig. S8, ESI $\dagger$ ). The X-ray analysis showed that the Ni1 $\cdots \mathrm{Rh} 1$ interatomic distance had been shortened to $2.7454(16) \AA$, with a bridging hydride ligand between the two

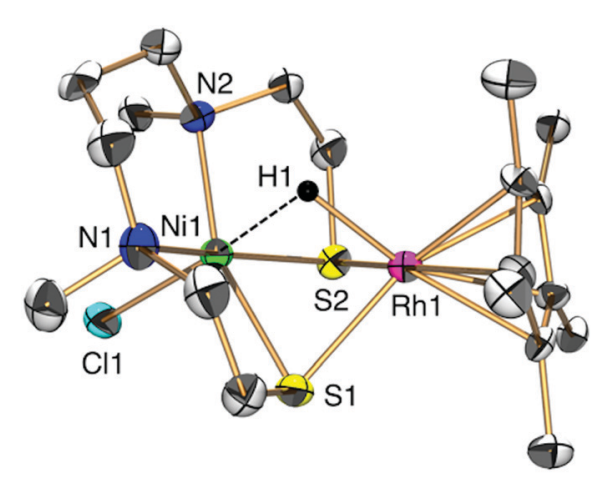

Fig. 1 ORTEP drawing of 2 with ellipsoids set at the $50 \%$ probability level. The hydrogen atoms of the ligand $\mathrm{X}\left(N, N^{\prime}\right.$-dimethyl-3,7-diazanonane1,9-dithiolato) and $\mathrm{C}_{5} \mathrm{Me}_{5}$ are omitted for clarity. Selected interatomic distances $[\AA \AA]$ and angles $\left[^{\circ}\right]$ : Ni1...Rh1 2.7454(16), Rh1-H1 1.84(9), Ni1-H1 1.96(9), Ni1-S1-Rh1 71.15(7) and Ni1-S2-Rh1 70.65(7) for 2. 
a)

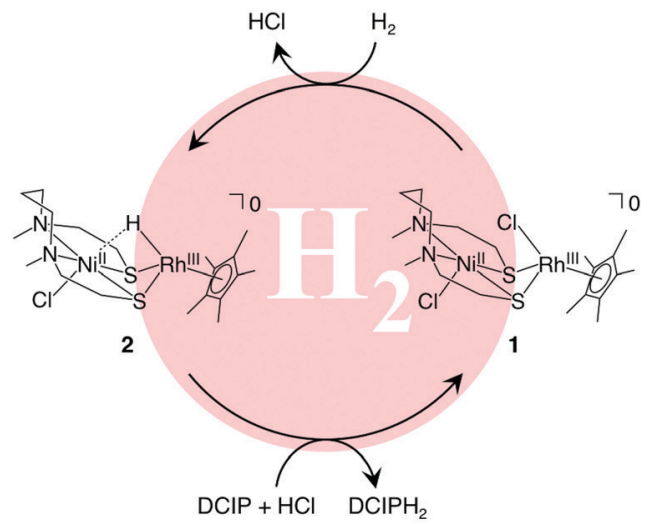

b)

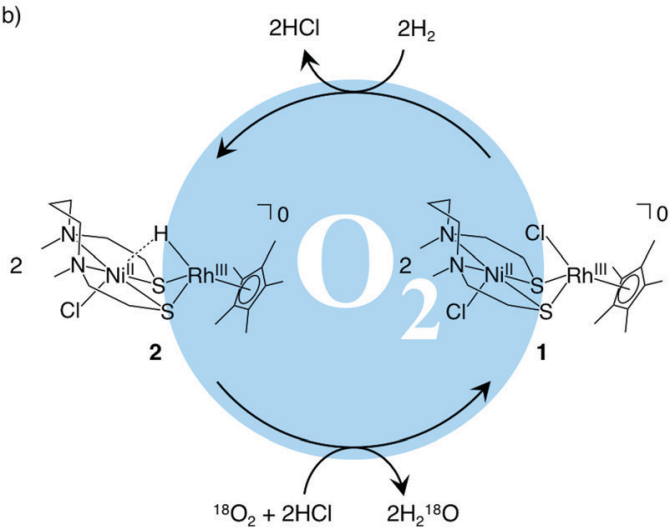

Fig. 2 Proposed catalytic reaction mechanisms for (a) $\mathrm{H}_{2}$-oxidation and (b) $\mathrm{O}_{2}$-reduction with NiRh complexes in water. DCIP: 2,6-dichlorobenzeneindophenol. $\mathrm{DCIPH}_{2}$ : reduced-form of DCIP.

metal centres (Fig. 1). This structural change upon the activation of $\mathrm{H}_{2}$ and complexation of the hydride is similar to that found in our other $[\mathrm{NiFe}] \mathrm{H}_{2}$ ase models and the natural $[\mathrm{NiFe}] \mathrm{H}_{2}$ ases themselves. ${ }^{1,7,9}$ The origin of the bridging hydride was derived from dihydrogen gas, as confirmed by the formation of a deuteride complex $\left[\mathrm{Ni}^{\mathrm{II}} \mathrm{Cl}(\mathrm{X})(\mu-\mathrm{D}) \mathrm{Rh}^{\mathrm{III}}\left(\eta^{5}-\mathrm{C}_{5} \mathrm{Me}_{5}\right)\right]$ (D-labelled 2) from the treatment of 1 with $\mathrm{D}_{2}$ (Fig. $\mathrm{S} 7$ and $\mathrm{S} 8, \mathrm{ESI} \dagger$ ).

We then investigated the catalytic properties of 1 by using 2,6-dichlorobenzeneindophenol (DCIP) as an acceptor of $2 \mathrm{e}^{-}$and $2 \mathrm{H}^{+}$ under stoichiometric conditions with 2 and catalytic conditions with 1 (eqn (1)). Under stoichiometric conditions (2:DCIP = 1:1) in the absence of $\mathrm{H}_{2}$ in water, 2 is capable of reducing DCIP to $\mathrm{DCIPH}_{2}$ (Fig. S9, S10 and Table S3, ESI $\dagger$ ). Under catalytic conditions (1:DCIP $=1: 27)$ in the presence of $\mathrm{H}_{2}$ in water (buffer solution), $\mathrm{H}_{2}$ reduces DCIP to DCIPH$H_{2}$ with the assistance of 1 (Fig. 2a). The catalytic reaction is pH-dependent (Fig. S11 and Table S4, ESI $\dagger$ ) and it shows a maximum turnover number (TON) value of 14.3-15.2 at pH 4.0-5.0 (TON, mol of $\mathrm{DCIPH}_{2} / \mathrm{mol}$ of $\mathbf{1}$ ), similar to our previously reported system. ${ }^{4}$<smiles>C[C+]=[P+][C+]=C1C(=O)C(Cl)=CC(=Nc2ccc(O)cc2)C=C1Cl</smiles>

The hydride complex 2 can also reduce $\mathrm{O}_{2}$ to $\mathrm{H}_{2} \mathrm{O}$ (Fig. 2b, Fig. S12 and Table S3, ESI $\dagger$ ). The $\mathrm{O}_{2}$-reduction in water was confirmed by an ${ }^{18} \mathrm{O}_{2}$-experiment wherein $\mathrm{H}_{2}{ }^{18} \mathrm{O}$ was formed from the reaction of 2 with ${ }^{18} \mathrm{O}_{2}$, as observed by gas chromatographymass spectrometry (GC-MS). The TON value (TON, [(mol of $\left.\mathrm{H}_{2}{ }^{18} \mathrm{O}\right) /$ (mol of 1)]/2) was determined to be 0.48 in the reaction using 1 with $\mathrm{H}_{2}$ as an electron donor (Table S4, ESI $\dagger$ ). ${ }^{10-12}$

Having satisfied ourselves that the NiRh catalyst was a successful analogue of our NiRu catalyst, we set about rendering it in a heterogeneous, solid-state form. To achieve this, we used dry distillation of $\mathbf{1}$ with carbon black, in pyrolysis experiments at $100-800{ }^{\circ} \mathrm{C}$ under vacuum (ca. 15-20 Pa). ${ }^{13}$ Following this process, the volatile elements were removed to mainly leave $\mathrm{Ni}$, $\mathrm{Rh}$ and $\mathrm{S}$ atoms. The structural properties of the resulting solids were analysed by thermogravimetry-differential scanning calorimetry (TG-DSC), X-ray photoelectron spectroscopy (XPS), elemental analysis, X-ray powder diffraction (XRD) analysis, (scanning) transmission electron microscopy ((S)TEM) and energy-dispersive X-ray spectroscopy (EDS) mapping (Table S5, ESI $\dagger$ ).

The thermal properties of $\mathbf{1}$ were investigated by TG-DSC under an $\mathrm{N}_{2}$ atmosphere (Fig. 3 and Fig. S13, ESI $\dagger$ ). Weight loss began around $250{ }^{\circ} \mathrm{C}$ and was mostly completed by about 400-450 ${ }^{\circ} \mathrm{C}$. Some endothermic peaks in the process suggest vaporization of the decomposed products that should mainly contain $\mathrm{Cl}, \mathrm{H}$ and $\mathrm{N}$ atoms, as detailed below.

XPS measurements also show that the structural change of 1 depends on the temperature of dry distillation (Fig. S14, ESI $\dagger$ ). Above $300{ }^{\circ} \mathrm{C}$, the binding energies at $162.3-163.6 \mathrm{eV}$ for $\mathrm{S} 2 \mathrm{p}_{3 / 2}$, 307.4-307.8 eV for $\mathrm{Rh} 3 \mathrm{~d}_{5 / 2}$ and $853.0 \mathrm{eV}$ for $\mathrm{Ni} 2 \mathrm{p}_{3 / 2}$ are observed in the XP spectra, which might be derived from metal sulfides coexisting with $\mathrm{Rh}^{0}{ }^{6}{ }^{6,14,15}$

XRD analysis also indicates the transformation of $\mathbf{1}$ to DDCs depending on the dry distillation temperatures (Fig. S15, ESI $\dagger$ ). Complex 1 should change to DDCs at $200-300{ }^{\circ} \mathrm{C}$ and then the DDCs could be structurally changed further at $700-800{ }^{\circ} \mathrm{C}$. The

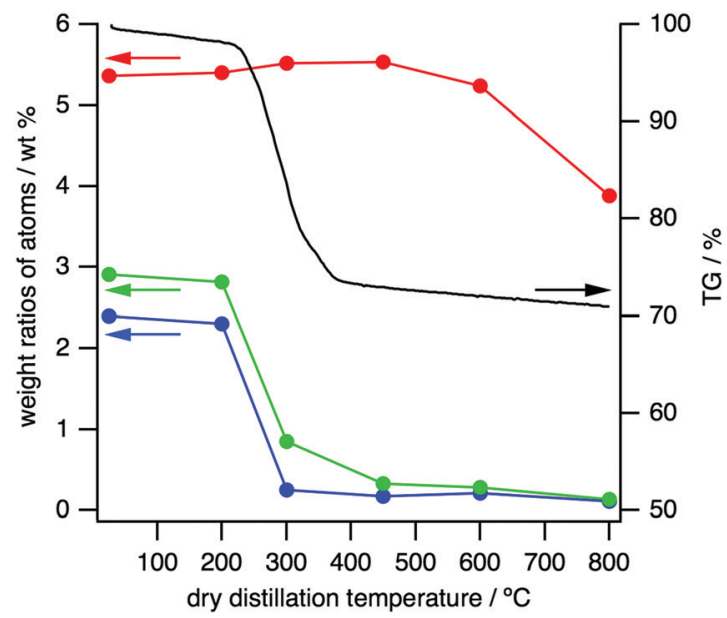

Fig. 3 A TG curve obtained from TG-DSC analysis of a mixture of 1 and carbon black ( $1: 1$ weight ratio) (black line), and dry distillation temperaturedependent ratios of $\mathrm{S}$ (red line), $\mathrm{N}$ (blue line) and $\mathrm{H}$ (green line) atoms in DDCs determined by elemental analysis. At the point of $25^{\circ} \mathrm{C}$, a mixture of 1 and carbon black (1:1 weight ratio) is used, i.e., no dry distillation. 
XRD patterns of DDCs prepared at $300-700{ }^{\circ} \mathrm{C}$ seem to be similar to those of $\mathrm{Rh}_{17} \mathrm{~S}_{15}$ and $\mathrm{Rh}_{3} \mathrm{~S}_{4},{ }^{15}$ but do not completely correspond to them. The DDC prepared at $800{ }^{\circ} \mathrm{C}$ might be attributed to the S-doped NiRh alloy. ${ }^{14 b}$

Elemental analyses were performed to determine the ratios of $\mathrm{C}: \mathrm{H}: \mathrm{N}: \mathrm{S}$, according to the heating temperatures (Fig. 3 and Table S6, ESI $\dagger$ ). The ratio of $\mathrm{N}$ decreased from $2.30 \%$ to only $0.25 \%$ upon raising the heating temperature from $200{ }^{\circ} \mathrm{C}$ to $300{ }^{\circ} \mathrm{C}$, with a similar trend for $\mathrm{H}$ (Table S6, ESI $\dagger$ ). These profiles are almost the same as the TG curve shown in Fig. 3 and strongly indicate that the weight loss at $200-300{ }^{\circ} \mathrm{C}$ is caused by vaporization of $\mathrm{N}$ - and $\mathrm{H}$-containing fragments. $\mathrm{S}$, however, only deceased from $5.36 \%$ to $3.88 \%$, even after heating to $800{ }^{\circ} \mathrm{C}$, indicating that the DDCs bear significant amounts of this element.

Bright-field (BF-)TEM, annular dark field (ADF-)STEM and STEM-EDS analyses were conducted to analyse the particle form and elemental distribution in the DDCs (Fig. 4 and Fig. S16, $\mathrm{ESI} \dagger$ ). At heating temperatures above $200{ }^{\circ} \mathrm{C}$, nanoparticles with a particle size of $50 \mathrm{~nm}$ or less were formed. Elemental mapping reveals that $\mathrm{Ni}, \mathrm{Rh}$ and $\mathrm{S}$ atoms are distributed homogeneously under $280{ }^{\circ} \mathrm{C}$ but inhomogeneously above $300{ }^{\circ} \mathrm{C}$.

Based on these results, we conclude that the homogeneous $\mathrm{Ni}^{\mathrm{II}}(\mu-\mathrm{S})_{2} \mathrm{Rh}^{\mathrm{III}}$ catalyst is converted into heterogeneous NiRhSbased catalysts by loss of $\mathrm{N}, \mathrm{H}$ and $\mathrm{Cl}$ atoms at $300-600{ }^{\circ} \mathrm{C}$, with a slight loss of $\mathrm{S}$ atoms at $800{ }^{\circ} \mathrm{C}$. $^{15}$

To examine the catalytic activities of DDCs, $\mathrm{H}_{2}$-oxidation and ${ }^{18} \mathrm{O}_{2}$-reduction are investigated in flask experiments. The DDCs are able to remember the reactivity of $\mathbf{1}$ to catalytically oxidize $\mathrm{H}_{2}$ and reduce ${ }^{18} \mathrm{O}_{2}$. The composition of NiRhS should remind us of [NiFe] $\mathrm{H}_{2}$ ases. The TON values of $\mathrm{H}_{2}$-oxidation and ${ }^{18} \mathrm{O}_{2}$-reduction are increased to 4.3 and 3.5 times higher than those of $\mathbf{1}$, respectively, by dry distillation (Tables S4 and S7, ESI $\dagger$ ).

Following the successful enhancement of the catalytic activities by dry distillation, we assembled polymer electrolyte fuel cells (PEFCs) with 1 or DDCs as anode and/or cathode catalysts (Fig. S17, ESI $\dagger$ ). A membrane electrode assembly (MEA) with Nafion membrane was made in the same way as molecular fuel cells.,16 a)

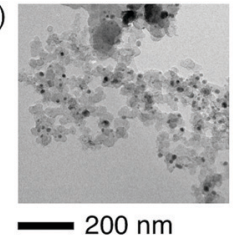

TEM

d)

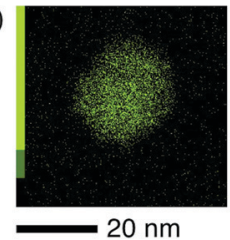

$\mathrm{Ni}$ b)

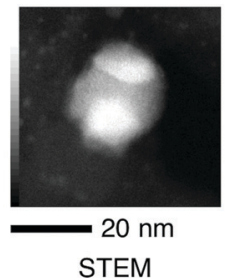

e)

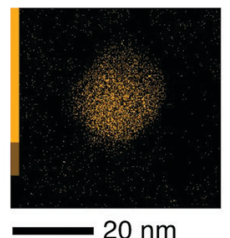

$\mathrm{S}$

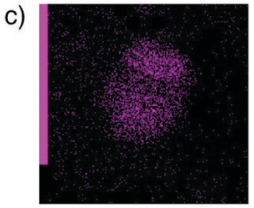

$20 \mathrm{~nm}$

$\mathrm{Rh}$
Fig. 4 (a) BF-TEM image, (b) ADF-STEM image and STEM-EDS elemental mappings of (c) $\mathrm{Rh},(\mathrm{d}) \mathrm{Ni}$ and (e) $\mathrm{S}$ of the dry-distilled catalyst (DDC) prepared at $600{ }^{\circ} \mathrm{C}$. a)

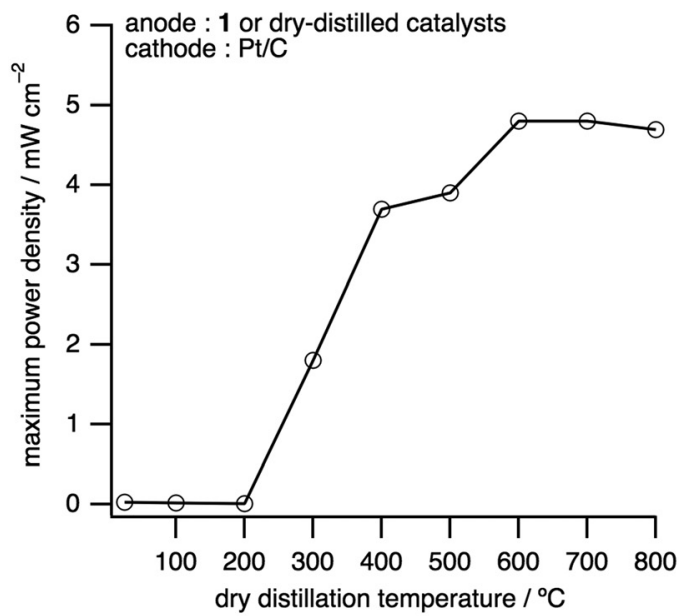

b)

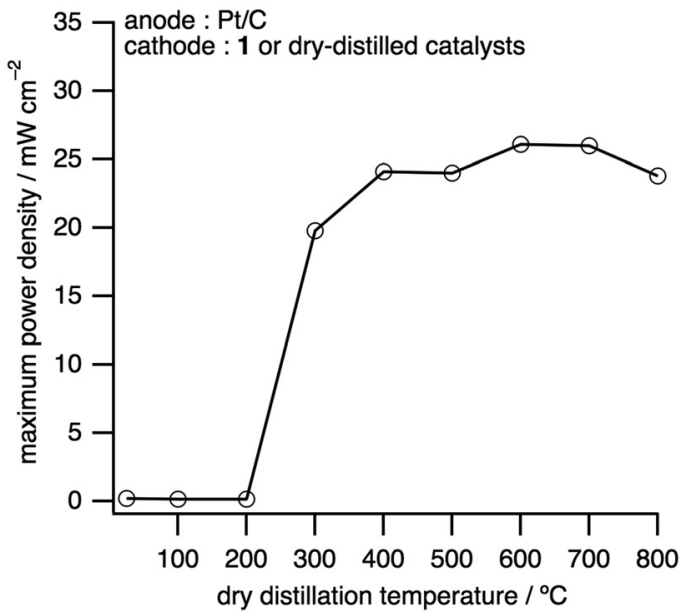

Fig. 5 Maximum power densities of $\mathrm{H}_{2}-\mathrm{O}_{2}$ fuel cells depending on the dry distillation temperature. At the dry distillation temperature of $25^{\circ} \mathrm{C}, \mathbf{1}$ is used as it is as a fuel cell catalyst. (a) Anode: 1 or DDCs. Cathode: Pt/C. (b) Anode: Pt/C. Cathode: 1 or DDCs.

The dependence of the maximum power densities on the dry distillation temperatures was investigated with DDCs as electrode catalysts for either the anode or the cathode (Fig. 5, Fig. S18, S19 and Tables S4 and S8, ESI $\dagger$ ). The maximum power densities and open circuit voltages (OCVs) obtained, where DDCs were employed as the anode and $\mathrm{Pt} / \mathrm{C}$ as the cathode, were significantly enhanced above $300{ }^{\circ} \mathrm{C}$ (Fig. 5a). The highest maximum power density of $4.85 \mathrm{~mW} \mathrm{~cm}^{-2}$ and OCV of $1.00 \mathrm{~V}$ were obtained by using the DDC prepared at $600{ }^{\circ} \mathrm{C}$ (Fig. 5a, Fig. S18 and Table S8, ESI $\dagger$ ). This maximum power density is 164 times higher than that of the precursor 1 and nearly 5\% of that of Pt. Thereafter, the same catalysts were applied as the cathode to fabricate and evaluate PEFCs. As before, the performance was drastically enhanced above the dry distillation temperature of $300{ }^{\circ} \mathrm{C}$, with the DDC prepared at $600{ }^{\circ} \mathrm{C}$ exhibiting the best performance with an OCV of $0.78 \mathrm{~V}$ and a maximum power density of $26.1 \mathrm{~mW} \mathrm{~cm}^{-2}$, which is $28 \%$ of that of Pt (Fig. 5b, Fig. S19 and Table S8, ESI $\dagger$ ). This power density is 139 times higher than that of $\mathbf{1 .}^{\mathbf{1 7}}$

Electrochemical aspects for $\mathrm{H}_{2}$-oxidation and $\mathrm{O}_{2}$-reduction with 1 and the DDC prepared at $600{ }^{\circ} \mathrm{C}$ were investigated by 
means of Tafel plots and impedance spectra (Fig. S20, S21 and Table S9, ESI $\dagger$ ). Exchange current densities of $0.0286 \mathrm{~mA} \mathrm{~cm}^{-2}$ and $0.0161 \mathrm{~mA} \mathrm{~cm}^{-2}$ were estimated for $\mathrm{H}_{2}$-oxidation and $\mathrm{O}_{2}$-reduction with 1, respectively, by Tafel plots (Fig. S20 and Table S9, ESI $\dagger$ ), which are slightly lower than those of our previously reported $\mathrm{Ni}^{\mathrm{II}} \mathrm{Ru}^{\mathrm{II}}$ complex. ${ }^{18}$ The exchange current densities can drastically increase by dry distillation, as determined to be $13.9 \mathrm{~mA} \mathrm{~cm}{ }^{-2}$ for $\mathrm{H}_{2}$-oxidation and $10.5 \mathrm{~mA} \mathrm{~cm}{ }^{-2}$ for $\mathrm{O}_{2}$-reduction, respectively, by using the DDC prepared at $600{ }^{\circ} \mathrm{C}$ (Fig. S20, ESI $\dagger$ ). This means that the DDC has higher charge-transfer ability on the electrode. In impedance spectra, no Warburg impedances were observed for the DDC, which indicates fast gas diffusion and rapid dissociative adsorption, different from 1 (Fig. S21, ESI $\dagger$ ).

Finally, we investigated the characteristics of a fuel cell using the DDCs prepared at $600{ }^{\circ} \mathrm{C}$ as both the anode and the cathode (Fig. S22b and Tables S4, S8, ESI $\dagger$ ). The fuel cell generated an OCV of $0.78 \mathrm{~V}$ and a maximum power density of $4.53 \mathrm{~mW} \mathrm{~cm}^{-2}$, a 449-fold improvement in maximum power density over 1 as a catalyst for both electrodes (Fig. S22, ESI $\dagger$ ).

In this paper, we have shown that a $\mathrm{Rh}$ analogue of our previous [NiFe] $\mathrm{H}_{2}$ ase models successfully functions in a similar manner. Crucially, however, we have been able to transform it by dry distillation into heterogeneous catalysts with maximum power densities $5-28 \%$ that of platinum. While these new catalysts fall short of the performance of platinum, they point the way towards linking the stepwise development of new, heterogeneous, fuel cell catalysts with the development of homogeneous organometallic catalysts.

This work was supported by JST CREST Grant Number JPMJCR18R2, Japan, JSPS KAKENHI Grant Numbers JP26000008 (Specially Promoted Research), JP18H02091, and JP19K05503 and the World Premier International Research Center Initiative (WPI), Japan.

\section{Conflicts of interest}

There are no conflicts to declare.

\section{Notes and references}

1 (a) S. Ogo, R. Kabe, K. Uehara, B. Kure, T. Nishimura, S. C. Menon, R. Harada, S. Fukuzumi, Y. Higuchi, T. Ohhara, T. Tamada and
R. Kuroki, Science, 2007, 316, 585; (b) S. Ogo, Coord. Chem. Rev., 2017, 334, 43.

2 (a) X. Yang, L. C. Elrod, J. H. Reibenspies, M. B. Hall and M. Y. Darensbourg, Chem. Sci., 2019, 10, 1368; (b) C. Wombwell, C. A. Caputo and E. Reisner, Acc. Chem. Res., 2015, 48, 2858.

3 W. Lubitz, H. Ogata, O. Rüdiger and E. Reijerse, Chem. Rev., 2014, 114, 4081.

4 (a) T. Matsumoto, B. Kure and S. Ogo, Chem. Lett., 2008, 37, 970; (b) T. Matsumoto, T. Ando, Y. Mori, T. Yatabe, H. Nakai and S. Ogo, J. Organomet. Chem., 2015, 796, 73.

5 T. Matsumoto, K. Kim and S. Ogo, Angew. Chem., Int. Ed., 2011, 50, 11202.

6 (a) N. Singh, M. Gordon, H. Metiu and E. McFarland, J. Appl. Electrochem., 2016, 46, 497; (b) Y. Shimizu, S. Yamamoto and M. Ono, Jpn. Kokai Tokkyo Koho, 2007, JP 200787827; (c) B. Chen, G. Ma, Y. Zhu, J. Wang, W. Xiong and Y. Xia, J. Power Sources, 2016, 334, 112; (d) Y. Li and T. V. Nguyen, J. Power Sources, 2018, 382, 152; (e) R. W. Reeve, P. A. Christensen, A. J. Dickinson, A. Hamnett and K. Scott, Electrochim. Acta, 2000, 45, 4237; $(f)$ M. Shen, C. Ruan, Y. Chen, C. Jiang, K. Ai and L. Lu, ACS Appl. Mater. Interfaces, 2015, 7, 1207; $(g)$ F. Wang, P. Zhang, S. You, J. Du, B. Jiang, X. Li, Z. Cai, N. Ren and J. Zou, J. Colloid Interface Sci., 2020, 567, 65; (h) Y. Sun, Y. Dai, Y. Duan, X. Xu, Y. Lv, L. Yang and J. Zou, Carbon, 2017, 119, 394; (i) D. Guo, S. Han, R. Ma, Y. Zhou, Q. Liu, J. Wang and Y. Zhu, Microporous Mesoporous Mater., 2018, 270, 1; $(j)$ P. Chandran, A. Ghosh and S. Ramaprabhu, Sci. Rep., 2018, 8, 3591; (k) F. Möller, S. Piontek, R. G. Miller and U.-P. Apfel, Chem. - Eur. J., 2018, 24, 1471.

7 S. Ogo, K. Ichikawa, T. Kishima, T. Matsumoto, H. Nakai, K. Kusaka and T. Ohhara, Science, 2013, 339, 682.

8 (a) R. M. Bullock and M. L. Helm, Acc. Chem. Res., 2015, 48, 2017; (b) B. C. Manor and T. B. Rauchfuss, J. Am. Chem. Soc., 2013, 135, 11895.

9 H. Ogata, K. Nishikawa and W. Lubitz, Nature, 2015, 520, 571.

10 T. Kishima, T. Matsumoto, H. Nakai, S. Hayami, T. Ohta and S. Ogo, Angew. Chem., Int. Ed., 2016, 55, 724.

11 P. Wulff, C. C. Day, F. Sargent and F. A. Armstrong, Proc. Natl. Acad. Sci. U. S. A., 2014, 111, 6606.

12 J. Fritsch, O. Lenz and B. Friedrich, Nat. Rev. Microbiol., 2013, 11, 106.

13 F. A. Westerhaus, R. V. Jagadeesh, G. Wienhöfer, M.-M. Pohl, J. Radnik, A.-E. Surkus, J. Rabeah, K. Junge, H. Junge, M. Nielsen, A. Brückner and M. Beller, Nat. Chem., 2013, 5, 537.

14 (a) J. F. Moulder, W. F. Stickle, P. E. Sobol and K. D. Bomben, Handbook of X-ray Photoelectron Spectroscopy, Physical Electronics Inc., Minnesota, 1995; (b) J. Lu, Z. Tang, L. Luo, S. Yin, P. K. Shen and P. Tsiakaras, Appl. Catal., B, 2019, 255, 117737.

15 J. Masud, T. V. Nguyen, N. Singh, E. McFarland, M. Ikenberry, K. Hohn, C.-J. Pan and B.-J. Hwang, J. Electrochem. Soc., 2015, 162, F455.

16 Annen, V. Bambagioni, M. Bevilacqua, J. Filippi, A. Marchionni, W. Oberhauser, H. Schönberg, F. Vizza, C. Bianchini and H. Grützmacher, Angew. Chem., Int. Ed., 2010, 49, 7229.

17 M. Lefèvre, J. P. Dodelet and P. Bertrand, J. Phys. Chem. B, 2002, 106, 8705.

18 T. Matsumoto, K. Kim, H. Nakai, T. Hibino and S. Ogo, ChemCatChem, 2013, 5, 1368. 